\title{
Study on the Problems and Countermeasures of Teaching Management in Colleges and Universities
}

\author{
Yuhai Li \\ Information Science and Engineering \\ Hebei Vocational College of Labor Relations \\ Shijiazhuang, China \\ hbsjzlyh@sina.cn
}

\author{
Jingtang Jia \\ Foundation Department \\ Handan Polytechnic College \\ Handan, China \\ hbhdjjt@sina.cn
}

\author{
Yushu Shi \\ Grammar Department \\ Handan Polytechnic College \\ Handan, China \\ hbhdsys@sina.cn
}

\begin{abstract}
With the continuous development of our economic and social, the macro and micro environment of the higher education in China have undergone significant changes. The innovation of teaching management in colleges and universities has become an inevitable. There are two main defects of the system of teaching management in colleges and universities in China. On the one hand, the fuzzy school localization lead to fuzzy in philosophy teaching management, even to deviate from the correct direction of development.On the other hand, teaching management system is rigid, lack of flexibility and humanization. This paper systematically analyzes the current problems in teaching management in colleges and universities, and proposes direction and countermeasures of the reform of teaching management.
\end{abstract}

Keywords-colleges and universities; teaching management; management innovation

\section{INTRODUCTION}

With the rapid development of emerging and new technology of the knowledge economy, China's social development has entered a new stage. It is an inevitable requirement for higher education of the society to develop innovative spirit and practical ability. Teaching management is the core of the management in colleges and universities, and is the important guarantee of the quality of personnel training[1]. At present, from the analysis of the domestic and foreign teaching management present situation, some advanced ideas have been varying degrees of concern and research in teaching management and the practice and exploration in some specific management work. Such as scientific, standardization, humanization, democratization, efficiency etc. But we started very late, though. We still have the certain gap compared with developed countries if we compared to the depth of theoretical study, research system, internal and external environment and conditions and other aspects of society as a whole. For ordinary college teaching management work, the important things are how to utilize home and abroad advanced management idea and the reform of research results. It requires to be combined with China's outstanding traditional culture to explore a line with its own characteristics and the needs of teaching reform and management of the road.

\section{THE EXISTING PROBLEMS IN THE TEACHING}

\section{MANAGEMENT OF COLLEGES AND UNIVERSITIES}

In recent years, the development of colleges and universities are facing new challenges due to the expansion of enrollment. The prominent contradiction is the development of quality unable to keep pace with the quantity expansion, which result in the teaching management in Colleges and universities have many problems either in understanding or in the management. It also affects the quality of talents cultivation.

We always pay more attention to the unity and the requirements for personnel training in teaching management for a long time while failed to give enough attention on the personality development of students, thus weakened the cultivation of students' innovative ability ${ }^{[2]}$. In the current undergraduate teaching work, there are still too pursuit tendency to academic or professional theoretical system integrity. We do not pay enough attention to the academic or professional problems and innovation.

\section{A. Inadequate Attention to the Teaching Management}

On the one hand, the school did not pay much attention to teaching tube position. In order to meet the need of improving teaching conditions and the rapid enlargement of the scale of the demand, all levels of government to increase investment in education and many universities also strive to raise funds invested in the construction of 
infrastructure and teaching equipment, such as carrying out the construction of classrooms, laboratories, administrative Office of public housing. School managers also increase the sports facilities, experimental equipment, network system, books and reference materials to strive to achieve the standard of Ministry of Education. The school only pay attention to the rapid increase in the number of but the funds of directly to the quality is limited, which react on the less of teaching management personnel training ,training funds and modern management equipment. Many schools have not even set up information and network educational administration management information system, which cannot master the teaching link information in a timely manner.

On the other hand, teaching management staff doesn't pay attention to their own work. The basic task of teaching management is: To study the teaching and management rules and improve the teaching management level. We should set up a stable teaching order to ensure the normal operation of teaching work and organize the implementation of teaching reform to strive to mobilize the enthusiasm of the teaching and learning of teachers and students. The teaching management work is thinking, dynamic, which change with the teaching objective and task change. We engaged in the teaching management as workers must recognize that teaching is to educate people, management is also the cultivation.

\section{B. The Prevalence of Bureaucracy in Senior}

\section{Administrative Staff}

"Bureaucracy" makes higher education stylized and result in management system innovation ability is poor and knowledge ability structure of education to cultivate talents are too old, which cannot adapt to the rapid economic development the demand for talent in today's society. The main reason is that the management theory of the higher education quality can't keep up with the cutting of the reform and development of higher education, especially to keep up with the situation of popularization of higher education development. Elite education, especially under the condition of planned economy mode of elite education has not been fundamentally changed. The goal of talent training, the model and the evaluation mechanism remains largely in the following century form the management paradigm.

\section{The Separation of Teaching and Learning}

Only attach importance to the management of "teaching" in the teaching management in Colleges and universities. On the one hand, school strengthens the training of the teachers, encourage teachers of regular education and strengthen supervision and management of the teachers teaching. On the other hand, school also increases the teaching materials, examination library and excellent course so as to improve the teaching quality. Some schools ignore the management of "science" for a long time. Some students lack enthusiasm for learning and don't to establish a correct view of learning, view of talent and employment outlook. They lack of ambition and motivation to learn and can't restrain their own. Some schools often do not focus on these aspects and think they belong to the students themselves instead of belong to the teaching quality management category. However, these also are key factors affecting the quality of teaching.

\section{The Lack of Innovation in Teaching Management}

Many colleges and universities teaching management just stays in the conventional management neglect or even abandon the innovation of teaching management. If the teaching management is to maintain the normal operation of norms under the conditions of the stick in the mud, blindly and not thinking explore the new management method and the new idea, then the management will be more and more narrower.

\section{THE COUNTERMEASURES FOR OPTIMIZING}

\section{TEACHING MANAGEMENT}

\section{A. Strengthening the Construction of Subjects}

First, the discipline is set to realize the nature of the school and the comprehensive advantages, and unique.We should change concept of one-sided pursuit of professional quantity, size and level. Secondly, we should accord to subject and social development needs of timely adjusting of specialist and professional direction, enhancing adaptability of professional. In the cultivation of talents, we should be combined with quality education and creative education $^{[3]}$. It is important to develop humane quality education that adhere to the general education and professional education, morals and personality as well as knowledge, ability and quality. We should insist on their aptitude when training on different objects to achieve diversification of talents training mode. Reform of personnel training model should be implemented into the curriculum, teaching methods and management methods, etc.

\section{B. Enhancing the Quality of Teaching Management}

First of all, the school party and government leaders as the teaching quality of person of the first responsibility to personally teaching quality and teaching work conference held regularly. The leaders have to study and solve new situations, new problems of undergraduate teaching work and continue to promote the concept of innovation, system innovation and innovation of school work and improve the quality of teaching. Secondly, the school should organize regular teaching seminars to improve the teaching quality of teachers. Finally, the school should strengthen the control of teaching process and organize supervision at all levels in-depth classroom and regular feedback.

\section{Setting up Supervision Organization of Teaching Management}

First of all, colleges and universities can set up a series of independent schools existing administrative system of teaching management and supervision organization. Let they be responsible for the professional and interdisciplinary teaching management rules and regulations and presided over the implementation. In this way that can avoid the phenomena of "bureaucratic" spread and extension of the teaching management works to a certain extent. Making teaching management to a certain extent, transparency and the authority of the supervision and management and for different professional, different disciplines multiple independent development of open access. Second, improve the management level of staff members and making staff members work more organized 
and targeted ${ }^{[4]}$. For example, to deepen the teaching secretary is responsible for the service of knowledge, professional knowledge and related management knowledge, and conduct quantitative evaluation of their work. For example, to deepen the teaching secretary is responsible for the service of knowledge, professional knowledge and related management knowledge, and conduct quantitative evaluation of their work. Regular work carries on the quantitative evaluation on it and we need to do more special. Post duty clear, on the one hand, it can be more accurate on quantitative assessment and on the other hand, it is clearer on accident "accountability" related teaching, which is to a certain degree of harmony for the related work in coordination of teachers.

\section{Emphasizing on the Management of Learning}

Any kind of teaching management system and measures should help students to fully mobilize the enthusiasm and creativity, which is good to cultivate the students' innovative spirit and practical ability. We should change the function of teaching management such as abandon the nanny, closed-end management, but implement flexible and strict management. Correct understanding and dealing with the relationship between unified requirements and individuality development, strict management and create a relaxed learning atmosphere, relationship of administrative management and academic management ${ }^{[5]}$. Correct understanding and dealing with the relationship between unified requirements and individuality development, strict management and create a relaxed learning atmosphere, the relationship between the relationship of administrative management and academic management. We should establish the concept of "great management" and organically combine teaching and educating people, scientific research and, management education, service education, environment education.

\section{E. Improving the Innovative Spirit of the Teaching}

\section{Management Team}

Teaching management personnel must have good ideological and political quality and high service quality can to promote the improvement of the teaching quality as they are the constitutor and executor for the school teaching management policy. Every teaching manager should establish a sense of quality brand and service consciousness. The school needs to train teaching management staff regularly and offer them further education and a high level of education opportunity to the innovation of teaching management and teaching management idea's development. The school should improve the knowledge structure; improve the theoretical level and operational capacity to carry out regular teaching management of academic exchange activities.

\section{ACKNOWLEDGMENT}

In the college leadership, the success of the reform in three questions: The first is top management how to change the management idea. The second is how to middle-level managers understand the management reform and the last is grass-roots management execution management system. Training quality management system of higher education and the quality is directly related to the talent. We look forward to this problem in the reform and construction of a new round of is to solve a proper position and the experience of the reform of talent showing itself has a number of more scientific, more perfect teaching management system, for the Chinese higher education modernization lay a more solid foundation. In a word, to strengthen the teaching management is the comprehensive implementation of quality education and a powerful guarantee to complete the teaching task. Only set up a "people-oriented" concept of teaching administration and perfect teaching management system, improve the quality of teaching management staff, use modern teaching management methods and means can realize University's teaching management reform and improve the teaching level.

\section{REFERENCES}

[1] Yikang Cheng, Several problems about teaching quality and teaching staff construction in current higher vocational colleges, Journal of Suzhou Vocational University, vol.11, pp.9-10, 2004.

[2] Huifang Mao, Questions and countermeasures on the development of higher vocational education under the new situation, Technology and Innovation Management, vol.4, pp.24-26, 2007.

[3] Liyan Ji, On the opportunity and challenge faced to profession college education and countermeasures, Journal of Liaoning Institute of Science and Technology, vol.9, pp.63-64, 2007.

[4] Bangkou Chang. The thought of modern social education and management of students, Gansu Science and Technology, vol.24, pp.176-178, 2008.

[5] Chengwu Ruan. On the social construction of the function of Government Education, Journal of the Chinese Society of Education, vol.47, pp.28-40, 2009. 